\title{
Proposed Plan for the Burma Road Rubble Pit (231-4F)
}

by

E. Palmer

Westinghouse Savannah River Company

Savannah River Site

Aiken, South Carolina 29808

\section{MASTER}

\section{DOE Contract No. DE-AC09-89SR18035}

This paper was prepared in connection with work done under the above contract number with the U.S. Department of Energy. By acceptance of this paper, the publisher and/or recipient acknowledges the U.S. Government's right to retain a nonexclusive, royalty-free license in and to any copyright covering this paper, along with the right to reproduce and to authorize others to reproduce all or part of the copyrighted paper. 


\section{DISCLAIMER}

Portions of this document may be illegible electronic image products. Images are produced from the best available original document. 


\section{United States Department of Energy}

Savannah River Site

\section{Proposed Plan for the Burma Road Rubble Pit (231-4F) (U)}

WSRC-RP-95-1531

Revision 1

November 19.95

Westinghouse Savannah River Company Savannah River Site Aiken, South Carolina 29808

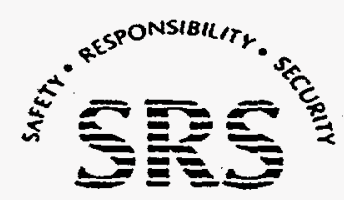
SAVANNAH RIVER SITE PREPARED FOR THE U.S. DEPARTMENT OF ENERGY UNDER CONTRACT DE-AC09-89SR180 5 


\section{DISCLAIMER}

\section{DISCLAIMER}

This report was prepared as an account of work sponsored by an agency of the United States Government. Neither the United States Government nor any agency thereof, nor any of their employees, makes any warranty, express or implied, or assumes any legal liability or responsibility for the accuracy, completeness, or usefulness of any information, apparatus, product, or process disclosed, or represents that its use would not infringe privately owned rights. Reference herein to any specific commercial product, process, or service by trade name, trademark, manufacturer, or otherwise does not necessarily constitute or imply its endorsement, recommendation, or favoring by the United States Government or any agency thereof. The views and opinions of authors expressed herein do not necessarily state or reflect those of the United States Government or any agency thereof.

This report has been reproduced directly from the best available copy.

Available to DOE and DOE contractors from the Office of Scientific and Technical Information, P.O. Box 62, Oak Ridge, TN 37831; prices available from (615) 576-8401.

Available to the public from the National Technical Information Service, U.S. Department of Commerce, 5285 Port Royal Road, Springfield, VA 22161. 
Table of Contents

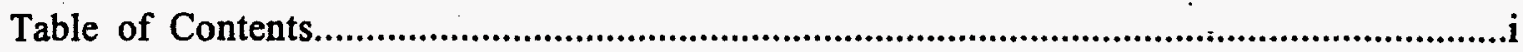

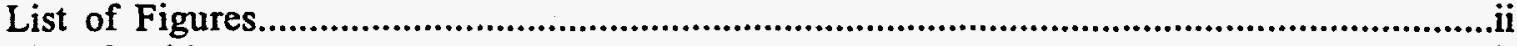

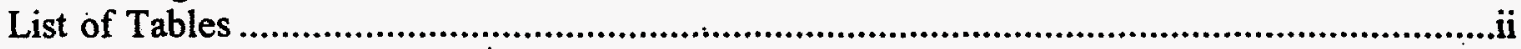

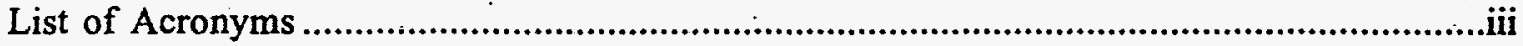

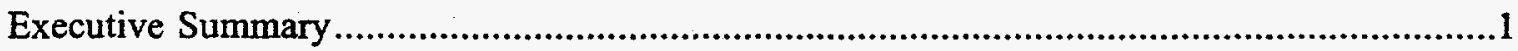

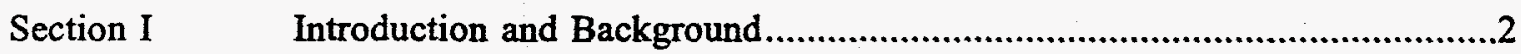

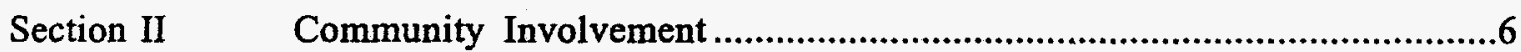

Section III Scope and Role of Operable Unit or Response Action Within the Site Strategy ................................................................................................

Section IV Media Specific Operable Unit - The BRRP Source Unit...............................9

Section IV.A Unit Description, History, and Media to be Addressed..............................................................

Section IV.B Operable Unit Risks.............................................11

Section IV.C Summary of Considered Alternatives .......................13

Section IV.D Summary of the No Action Alternative......................16

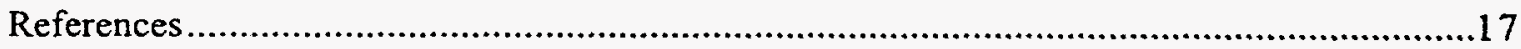

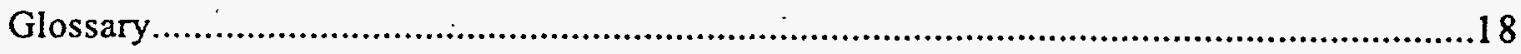




\section{List of Figures}

Figure 1: Location of the Burma Road Rubble Pit at the Savannah River Site ..................3

Figure 2: $\quad$ Location of the Burma Road Rubble Pit Waste Unit ......................................5

Figure 3: $\quad$ Burma Road Rubble Pit Regional Groundwater Flow Map (Second Quarter 1994). .8

Figure 4: General Configuration of the Burma Road Rubble Pit 10

\section{List of Tables}

Table 1: $\quad$ Current Land Use - Noncarcinogenic Hazard Index.

Table 2: $\quad$ Current Land Use - Carcinogenic Risks .....................................................14

Table 3: $\quad$ Future Land Use - Noncarcinogenic Hazard Index...................................14

Table 4: $\quad$ Future Land Use - Carcinogenic Risks 


\section{List of Acronyms}

ARARs Applicable or Relevant and Appropriate Requirements

BRR Burma Road Rubble Pit well designation

BRRP Burma Road Rubble Pit

CERCLA Comprehensive Environmental Response, Compensation and Liability Act

COĆ Constituents of Concern

COPCs Constituents of Potential Concern

DOE United States Department of Energy

EPA United States Environmental Protection Agency

FFA Federal Facility Agreement

FS Feasibility Study

FSL F-Area Inactive Process Sewer Line (well designation).

GPR Ground Penetrating Radar

HI Hazard Index

HQ Hazard Quotient

$\mathrm{mg} / \mathrm{kg} \quad$ milligram/kilogram

NCP National Oil and Substances Pollution Contingency Plan

NPL National Priorities List

OU Operable Unit

$\mathrm{pCi} / \mathrm{L} \quad$ picoCuries/Liter

PIP · Public Involvement Plan

P P Proposed Plan

RCRA Resource Conservation and Recovery Act

RID Reference Doṣe Factor

RFI RCRA Facility Investigation

RI Remedial Investigation

ROD. Record of Decision

SCDHEC South Carolina Department of Health and Environmental Control

SRS Savannah River Site

T\&E Threatened and Endangered

WSRC Westinghouse Savannah River Company 


\section{EXECUTTVE SUMMARY}

This Proposed Plan (PP) is being issued by the U.S. Department of Energy (DOE), which functions as the lead agency for the Savannah River Site (SRS) remedial activities, with concurrence by the U.S. Environmental Protection Agency (EPA) and the South Carolina Department of Health and Environmental Control (SCDHEC). The purpose of this PP is to describe the preferred alternative for addressing the Burma Road Rubble Pit (BRRP) source unit soils (231-4F) located at the SRS in Aiken, South Carolina and to provide an opportunity for public input into the remedial action selection process. The PP also provides a summary of the remedial investigation activities and the baseline risk assessment that were completed for the BRRP unit. Section 117(a) of the Comprehensive Environmental Response, Compensation, and Liability Act (CERCLA), as amended, requires publication of a notice of proposed remedial actions.

The results of the Resource Conservation and Recovery Act (RCRA) Facility Investigation (RFI)/Remedial Investigation $(\mathrm{RI})$ indicate that the BRRP source unit soils pose minimal risk to human health or the environment. Therefore, the DOE, EPA, and SCDHEC are proposing that no action is needed at the BRRP source unit soils. No other alternatives were considered. This is a proposed final CERCLA action for the BRRP source unit soils only.

The only soil contamination found at the BRRP source unit was arsenic at a concentration of $1.74 \mathrm{mg} / \mathrm{kg}$ which resulted in risks for the future residential adult $(1.9 \mathrm{x}$ $10^{-6}$ )- and for the future residential child $(2.8$ $x 1^{-6}$ ) that slightly exceeded the one in one million EPA target. Cancer risks are related to the EPA target risk range of one in ten thousand to one in one million for incremental cancer risks at National Priorities List (NPL) sites. It should be noted that arsenic was used as a component of agricultural chemicals in the period before $\mathrm{SRS}$ existed. Thus, the detected value may be a result of farming activities in the 1930's through 1950. The BRRP background concentration for arsenic averaged 3.34 $\mathrm{mg} / \mathrm{kg}$ for the subsurface soils (10-12 feet). Background concentrations of arsenic were not detected in the surface soils (0-2 feet).

Although there - is groundwater contamination (e.g., carbon tetrachloride, bis(2-ethylhexyl) phthalate, nitrate, cesium137 , radium, and tritium) beneath the BRRP, the groundwater contamination is due to migration from upgradient sources such as the F-Area Inactive Process Sewer Lines and thus will not be addressed in this remedial action. Following an investigation on upgradient groundwater contaminant sources, a determination will be made as to what corrective action might be appropriate for the groundwater beneath the BRRP.

Based on the results of the remedial investigation, it is proposed that no remedial action is necessary for the BRRP source unit soils. Only non-hazardous, inert material (e.g., wood, trash, wire, bottles, plastic, concrete, etc.) was placed at the BRRP. A notation on the deed to the facility property that will in perpetuity notify any potential purchaser of said property that the land has been used for the management and disposal of non-hazardous, inert construction type debris and material will also be recorded with the local zoning authority or the authority with jurisdiction over local land use. The notification will include a survey plat of the area prepared and certified by a professional land surveyor.

Community involvement in the remedial action selection process for the BRRP source unit soils is strongly encouraged. All submitted comments will be reviewed and considered. A Responsiveness Summary to address issues raised during the public comment period will be made available with the Record of Decision (ROD). 


\section{SECTION I}

\section{INTRODUCTION AND BACKGROUND}

\section{Introduction}

This PP is issued by the DOE, which functions as the lead agency for SRS remedial activities, and with concurrence by the EPA and SCDHEC. The purpose of this $P P$ is to describe the preferred alternative for addressing the BRRP source unit located at the SRS in Aiken, South Carolina.

The results of the RFI/RI indicate that the BRRP source unit soils pose minimal risk to human health or the environment. Therefore, the DOE, EPA, and SCDHEC are proposing that no action is needed at the BRRP source unit. This is a proposed final CERCLA action for the BRRP source unit soils only.

On December 21, 1989, SRS was included on the National Priorities List (NPL). This inclusion created a need to integrate the established RFI Program with CERCLA requirements to provide for a focused environmental program. In accordance with Section 120 of CERCLA, DOE has negotiated a Federal Facility Agreement (FFA, 1993) with EPA and SCDHEC to coordinate remedial activities at SRS into one comprehensive strategy. which fulfills these dual regulatory requirements.

Public participation requirements are listed in Sections 113 and 117 of CERCLA. These requirements include establishment of an Administrative Record File that documents the selection of remedial alternatives and allows for review and comment by the public regarding those alternatives. The Administrative Record File must be established "at or near the facility at issue." The SRS Public Involvement Plan (PIP) (DOE, 1994) is designed to facilitate public involvement in the decision-making process for permitting, closure, and the selection of remedial alternatives. Section 117(a) of CERCLA, 1980 requires publication of a notice of any proposed remedial action.
This PP is a summary of the Administrative Record File leading to the preferred alternative. This PP fulfills the requirements of CERCLA Section 117 (a) by providing the public an opportunity to participate in the selection of a remedial action. The PP presents the preferred alternative and the rationale for selecting the alternative. DOE, in consultation with EPA and SCDHEC, will select the appropriate final remedial action to be performed at the BRRP source unit soils following a public comment period. The final decision will be made only after the public comment period has ended and all comments submitted have been reviewed and considered.

In order to gain a better understanding of CERCLA activities as they pertain to the BRRP source unit, the public is encouraged to review the Administrative Record File for this unit. Refer to Section II of this document for information regarding availability and access.

\section{Background}

SRS occupies approximately 310 square miles of land adjacent to the Savannah River, principally in Aiken and Barnwell counties of South Carolina (Figure 1). SRS is a secured U.S. Government facility with no permanent residents. SRS is located approximately 25 miles southeast of Augusta, Georgia and 20 miles south of Aiken, South Carolina.

SRS is owned by the U.S. DOE. Management and operating services are provided by Westinghouse Savannah River Company (WSRC). SRS has historically produced tritium, plutonium, and other special nuclear materials for national defense: SRS has also provided nuclear materials for the space program and for medical, industrial, and research efforts. Chemical and radioactive wastes are byproducts of nuclear material production processes. Hazardous substances, as defined 


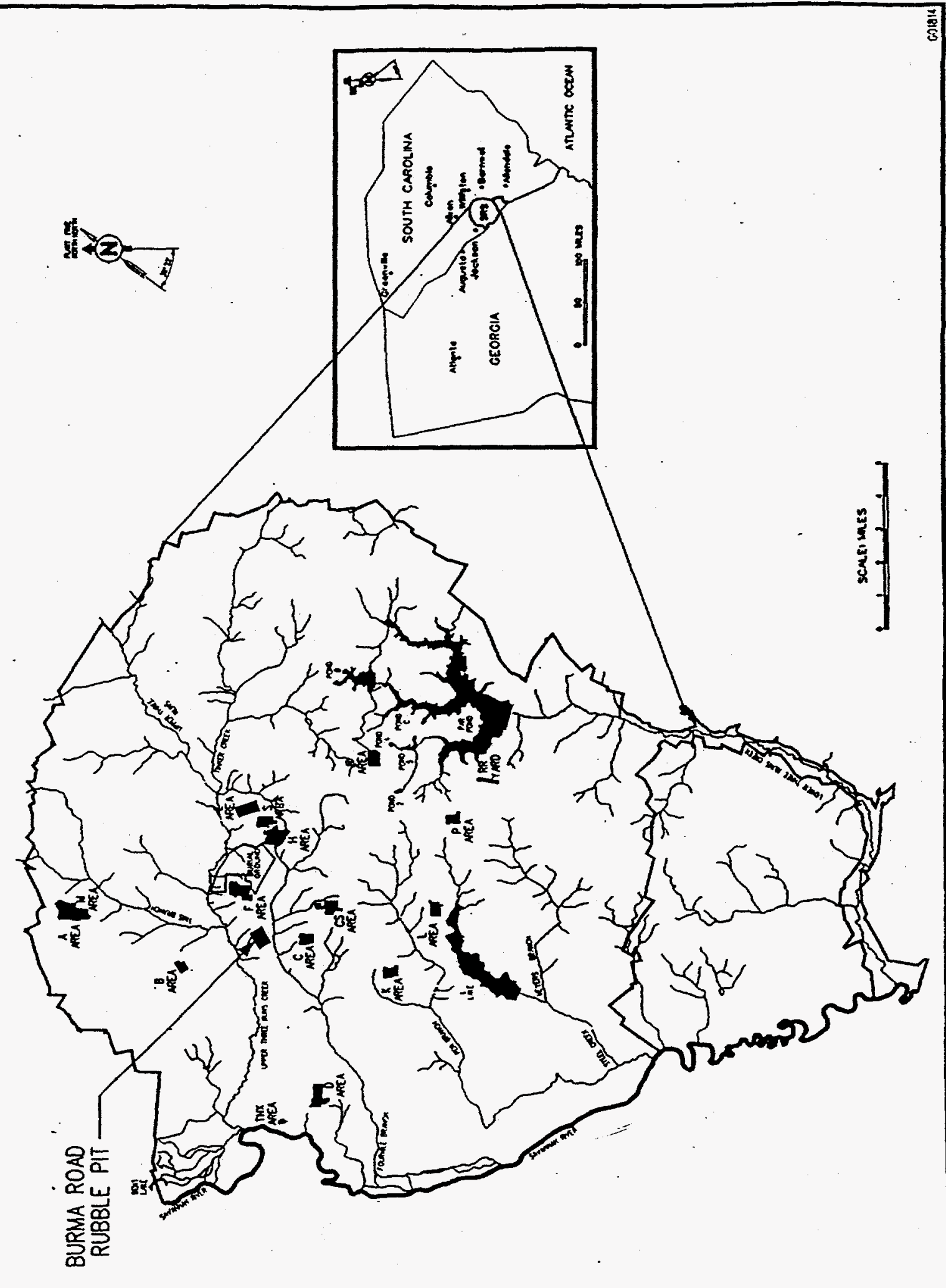

Figure 1. Location of the Burma Road Rubble Pit at the Savannah River Site. 
by CERCLA, are currently present in the environment at SRS.

SRS manages materials that are regulated under RCRA. Certain SRS activities have required operating or post-closure permits under RCRA. 'SRS received a RCRA hazardous waste permit from SCDHEC on September 30, 1987. Part V of the permit mandates that SRS establish and implement an RFI Program to fulfill the requirements specified in RCRA Section 3004(u).

The FFA lists the BRRP source unit (2314F; Figure 2) as a RCRA/CERCLA unit requiring further evaluation using an investigation/assessment process that integrates and combines the RFI process with the CERCLA RI to determine the actual or potential impact to human health and the environment.

Community involvement in consideration of this evaluation of alternatives for the BRRP source unit soils is strongly encouraged. All submitted comments will be reviewed and considered. A Responsiveness Summary to address issues raised by the public will be made available following the public comment period, if any comments have been received. Specific details on community participation in the corrective action selection process are provided in Section II. 


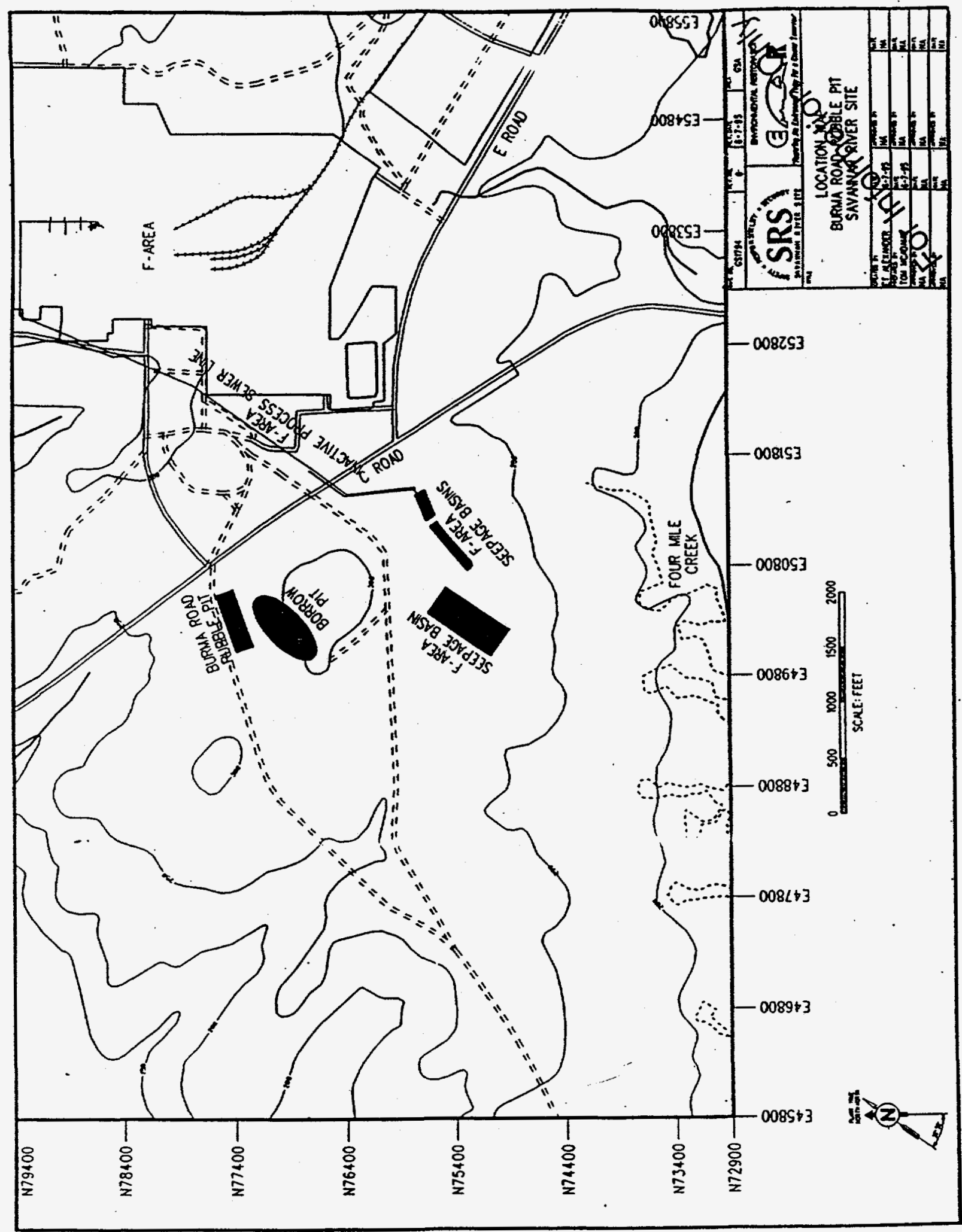

Figure 2. Location of the Burma Road Rubble Pit Waste Unit. 


\section{SECTION II}

\section{COMMUNITY INVOLVEMENT}

This document summarizes information that is provided in greater detail in the Administrative . Record File, which is available for review by the public at the following locations:

\section{U.S. Department of Energy}

Public Reading Room

Gregg-Graniteville Library

University of South Carolina-Aiken

171 University Parkway

Aiken, South Carolina 29801

(803) 641-3465

Thomas Cooper Library

Government Documents Library

University of South Carolina

Columbia, South Carolina 29208

(803) $777-4866$

Similar information is available through the repositories listed below:

Reese Library

Augusta College

2500 Walton Way

Augusta, Georgia 30910

(706) $737-1744$

Asa H. Gordon Library

Savannah State College

Tompkins Road

Savannah, Georgia 31404

(912) $356-2183$

DOE, EPA, and SCDHEC encourage the public to review this $P P$ and other documents contained in the Administrative Record File. DOE, EPA, and SCDHEC solicit public review and comment on all aspects of the PP.

The public will be notified of a public comment period through mailing of the SRS Environmental Bulletin, a newsletter sent to approximately 1400 citizens in South Carolina and Georgia, and through notices in the Aiken Standard, the Allendale Citizen
Leader, the Barnwell County Banner, the Barnwell People-Sentinel, the North Augusta Post, The State, and the Augusta Chronicle newspapers.

DOE will provide opportunity for a public meeting during the public comment period if interest is expressed. The public would be notified of the date, time, and location. At the meeting, the proposed action would be discussed and questions about the action will be answered. Written and oral comments will be accepted and considered prior to a final decision. To request a public meeting during the public comment period, to obtain more information concerning this $\mathrm{PP}$, or to submit written comments contact:

Mary Flora

Public Involvement

Westinghouse Savannah River Company

Aiken Commercial Center

139 Darlington Avenue

Aiken, South Carolina 29803

(803) 644-1814

DOE, EPA and SCDHEC strongly encourage community participation in the remedial action selection process for the BRRP source unit soils. A Responsiveness Summary to address issues raised by the public will be made available following the public comment period, if any comments have been received.

DOE, in consultation with EPA and SCDHEC, will select the appropriate final remedial action to be performed at the BRRP source unit soils following a public comment period. The alternative chosen must be protective of human health and the environment and comply with all Federal and state environmental laws. 


\section{SECTION III}

\section{SCOPE AND ROLE OF OPERABLE UNIT OR RESPONSE ACTION WITHIN THE SITE STRATEGY}

The overall strategy for addressing the BRRP source unit was to: (1) characterize the waste unit delineating the nature and extent of contamination and identifying the media of concern (perform the RFI/RI); (2) perform a baseline risk assessment to evaluate media of concern, chemicals of concern, exposure pathways, and characterize potential risks; and (3) evaluate and perform a final action to remediate, as needed, the identified media(s) of concern.

The investigation and risk assessment have been completed for the BRRP source unit. Since the results of the investigation indicate that the BRRP source unit soils pose minimal risk to human health or the environment, no action is being recommended by this proposed plan. Only non-hazardous, inert material (e.g., wood, trash, wire, bottles, plastic, rubble, foam, concrete, etc.) was placed at the BRRP source unit. A notification will be placed in the Aiken County Records which will include a survey plat of the area prepared and certified by a professional land surveyor.

Although there is groundwater contamination (e.g., carbon tetrachloride, bis(2-ethylhexyl)phthalate, nitrate, cesium137 , radium, and tritium) beneath the BRRP, the groundwater contamination is due to migration from upgradient sources such as the F-Area Inactive Process Sewer Lines (Figure 2) and thus will not be addressed in this remedial action. The depth to the water table beneath the BRRP is 61 to 83 feet.

Figure 3 illustrates the regional groundwater flow direction in the vicinity of the BRRP. The map indicates west-northwestward flow of the shallow aquifer system groundwater in the BRRP area. Groundwater data from two nearby areas, the F-Area Seepage Basins and the F-Area Separations Facility which includes the Inactive Process Sewer Lines, suggest that these areas may have impacted the groundwater beneath the BRRP. The FArea Separations Facility is located approximately 2,000 feet northeast of the BRRP. The F-Area Seepage Basins are located approximately 1,100 feet to the southeast of the BRRP.

Following an investigation on upgradient groundwater contaminant sources, a determination will be made as to what corrective action might be appropriate.

The BRRP is a source control operable unit (OU) located within the Upper Three Runs Watershed. Several source control and groundwater OUs, including the $\mathrm{F}$ - and $\mathrm{H}$ Area Groundwater OU, within this watershed will be evaluated to determine impacts, if any, to associated streams and wetlands. It has been determined that the BRRP source control OU does not contribute contamination to the area groundwater or surrounding soils. The proposed action for the BRRP source unit soils is a final action.

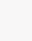
. 

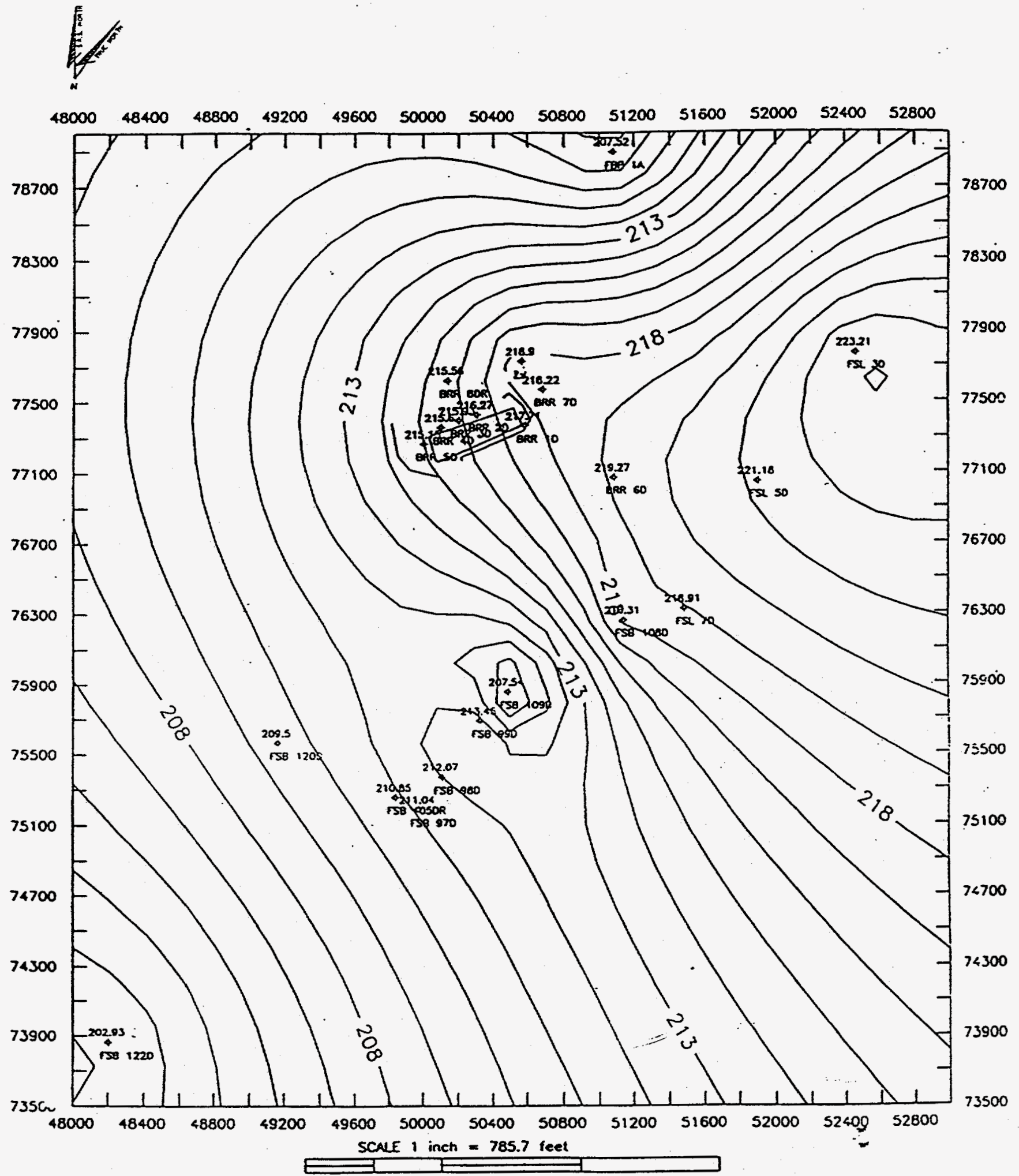

Figure 3. Burma Road Rubble Pit Regional Groundwater Flow Map (Second Quarter 1994). 


\section{SECTION IV}

\section{MEDIA SPECIFIC OPERABLE UNIT - THE BRRP SOURCE UNIT}

\section{Section IV.A Unit Description, History, and Media to be Addressed}

\section{Unit Description and Location}

The BRRP, 231-4F, is located approximately one-half mile southwest of the F-Area Separations Facility and onetenth mile southwest of C Road. The BRRP is between Upper Three Runs Creek (approximately 4000 feet to the northwest) and Four Mile Creek (approximately one mile to the southwest). A westward trending tributary to the Upper Three Runs Creek is located approximately 2,000 feet to the north. The BRRP ground surface elevation is approximately 290 feet mean sea level. Surface runoff is northwestward toward the tributary.

The BRRP consists of two unlined earthen pits dug into surficial soil and filled with various waste materials. The BRRP was originally reported to be 485 feet long, 125 to 150 feet wide, and at least 10 feet deep. A GPR survey, conducted in September 1988 , indicate that the BRRP area consists of two generally rectangular pits (GPR Zone 1 and GPR Zone 2, Figure 4), each about 400 feet long, up to 50 feet wide, and 10 feet deep. A small circular area (GPR Zone 3 , Figure 4) of disturbed soil was detected adjacent to these pits and is considered to have been used as a source of backfill for the pits.

The soil type that exists at BRRP consists of Udorthents. Udorthents are so extensively graded, exposed, transported, mixed, and compacted during earth moving and construction, that they can not be assigned to a particular soil series with a high level of confidence. The soils are generally more friable, but may be firmer due to compaction. Organic matter and other plant nutrients are usually low in these soils due to stripping and mixing, and extreme variations may occur laterally within very small distances. The soil $\mathrm{pH}$ may be low, and permeability is low to moderate.

\section{History of the Unit}

The BRRP was used from 1973 to 1983 for the disposal of dry inert rubble such as wood, trash, wire, bottles, plastic, rubble, foam, concrete, etc. No record of hazardous substances disposal at the BRRP has been found. In 1983, disposal at the BRRP ceased and it was backfilled with soil. The area is currently delineated by orange marker balls at the perimeter of the waste unit.

The BRRP RFI/RI investigation was conducted from November 1993 to February 1994. Samples were collected to characterize the chemical concentrations in soil, groundwater, sediments, and surface water at the BRRP.

Sampling and investigation activities are summarized below. Detailed information regarding sampling/investigation activities can be found in the Final RFI/RI Report for Burma Road Rubble Pit (23I-4F), (WSRC, 1995).

\section{Unit Assessment}

Surface and subsurface soil samples were collected from seventeen locations within the BRRP. Surface and subsurface soil sampling was conducted in areas of suspected contamination (e.g., the soil borings were located in areas where a soil gas anomaly was detected or adjacent to potential underground objects and/or areas of high metal concentrations as indicated by anomalies in the GPR, electromagnetic, or magnetometer surveys). Soil samples were collected from 0 to 2 feet (characteristic of surficial conditions) and from depths from 8 to 32 feet (characteristic of subsurface conditions). Overall, these sampling depths provide a representation of soil conditions above the fill material and at the bottom layer below the fill material. 


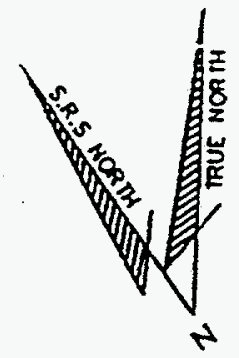

\section{LEGEND

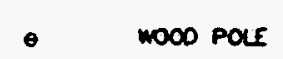 \\ - racow RAC}

DIIJ AREA OF DISTRRBD SOIL

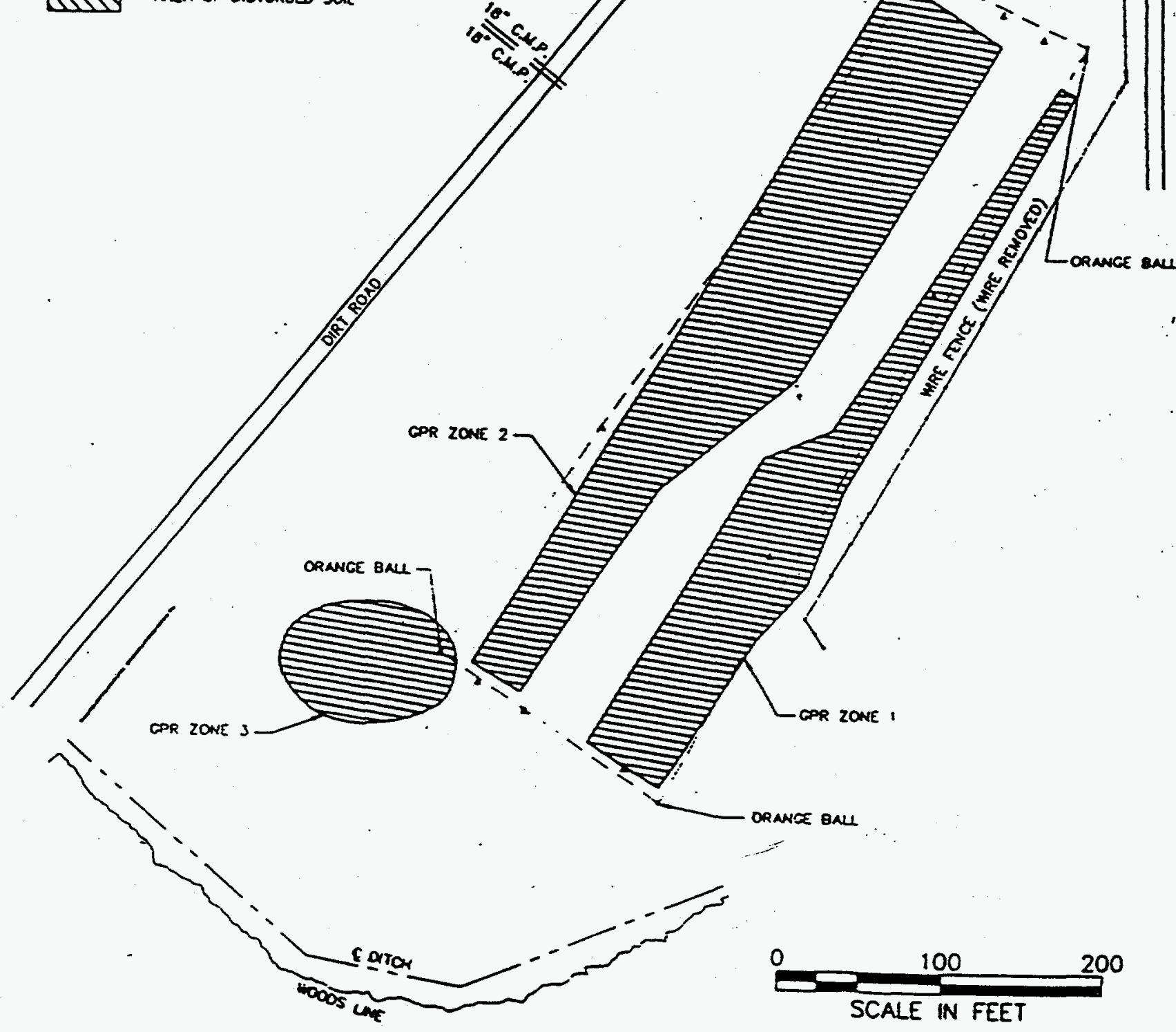

Figure 4. General Configuration of the Burma Road Rubble Pit. 
During the sampling, none of the soil borings encountered any containers (e.g., drums), liquid, sludge, or experienced a roddrop that would indicate a drum or container had been punctured. Only inert materials (e.g., wood, trash, wire, bottles, plastic, rubble, foam, concrete, etc.) were encountered during the soil sampling.

During the investigation, it was observed that standing water was present in a low lying area adjacent to the BRRP source unit. A field decision was made to collect two surface water samples in addition to the sampling specified in the Phase II RFI/RI Work Plan for the Burma Road Rubble Pit (WSRC, 1993) in order to be conservative and to provide additional characterization data. One surface water sample was collected from near the water's edge while the second surface water sample was collected from a high turbidity area within the pond.

One sediment sample was also collected (at a depth of 3 to 4 inches near the water's edge) from the borrow pit adjacent to the BRRP. This sample was collected to determine if the BRRP has impacted the quality of sediment in the adjacent borrow pit.

Two surface runoff soil (sediment) samples were collected at a depth of 6 to 12 inches. The samples were taken from a ditch located down slope of the unit. The results were used to determine if runoff from the unit has carried possible contamination to off site areas.

Four background subsurface soil samples were taken at a depth of 10 to $12 \mathrm{feet;}$ and, two background surface soil samples were collected at a depth of 0 to 2 feet. The purpose of the background samples was to gather data for statistical and comparative analysis against samples collected in the areas suspected of containing hazardous waste.

The background soil samples were located in areas that were away from GPR Zones 1, 2, 3 and were outside of the soil gas anomalies.
The background subsurface soil samples were drilled to a depth that corresponded to the base of the BRRP source unit (i.e., 10 to 12 feet below the ground surface). The background surface soil samples were located upgradient and at a sufficient distance from the BRRP source unit so as to preclude any impact from the unit.

Background surface water samples were unavailable because there is no upgradient body of surface water within a reasonable distance of the waste unit from which to obtain unit-specific background samples.

All samples were analyzed in accordance with EPA-approved protocols. The detailed analytical results are contained in the Quality Control Summary Report for the Burma Road Rubble Pit RFI/RI Unit Assessment (WSRC, 1994). Validation and verification of the analytical data were performed as part of the RFI/RI data review process; therefore, the data were considered acceptable for this evaluation.

Soil data from 0 to 2 feet were used in the risk assessment as the primary direct contact exposure interval for soils. Soils collected from 8 to 32 feet were evaluated for potential soil to groundwater migration.

Nine new groundwater monitoring wells were installed at varying depths in 3 three-well clusters. Of the 14 wells that exist at BRRP (new and existing), there are six wells that are considered to be upgradient wells. However, the entire BRRP is downgradient of the SRS F-Area Separations Facility and the entire BRRP well network may be impacted by groundwater migration from FArea.

\section{Section IV.B Operable Unit Risks}

The BRRP operable unit investigation was the investigation that addressed the rubble (potential source term), surrounding soils, and the groundwater under the facility. This section summarizes the baseline risk assessment information associated with the BRRP operable unit. It should be noted, 
however, that the remedial action proposed by this plan is for the BRRP source unit soils only. The groundwater contamination will be addressed following an investigation on upgradient contaminant sources.

\section{Human Health Risk Assessment}

As part of the investigation/assessment process for the BRRP source unit, a risk assessment was performed using the data generated during the assessment phase. Detailed information regarding the development of contaminants of potential concern, the fate and transport of contaminants, and the risk assessment can be found in the Final RFI/RI Report for Burma Road Rubble Pit (231-4F), (WSRC, 1995).

The process of designating the constituents of potential concern (COPCs) was based on consideration of background concentrations, frequency of detection, the relative toxic potential of the chemicals, and chemical nutrient status. COPCs are the constituents that are potentially site-related and whose data are of sufficient quality for use in the risk assessment. COPCs included volatile organic compounds, semi-volatile organic compounds, metals and other inorganic analytes, and radionuclides identified through approved site characterization activities.

An exposure assessment was performed to provide an indication of the potential exposures which could occur based on the chemical concentrations detected during sampling activities. The only existing (current) exposure scenario identified for the BRRP were for environmental researchers who may work or traverse the BRRP on an intermittent/limited basis. Future exposure scenarios identified for the BRRP included future environmental researchers as well as conservative future residential adult and child and a occupational worker.

Per EPA guidance, the carcinogenic (cancer) risks and non-carcinogenic hazards should be calculated to determine the appropriate remedial action for a waste unit.
Cancer risks are estimated as the incremental probability of an individual developing cancer over a lifetime as a result of pathway-specific exposure to carcinogenic contaminants. The risk to an individual resulting from exposure to nonradioactive chemical carcinogens is expressed as the increased probability of cancer occurring over the course of a 70 year lifetime. Cancer risks are related to the EPA target range of one in ten thousand $\left(1.0 \times 10^{-4}\right)$ to one in one million $\left(1.0 \times 10^{-6}\right)$ for incremental cancer risk at NPL sites. Risk levels at or above $1.0 \times 10^{-4}$ are considered significant. In order to account for simultaneous exposure to multiple carcinogens through a given pathway, the risk calculated for each individual carcinogen in that medium were summed to obtain an estimate of the total cancer risk for the pathway.

Non-carcinogenic effects are evaluated by comparing an exposure level over a specified time period (e.g., lifetime) with a reference dose (RfD) derived for a similar exposure period. To evaluate the non-carcinogenic effects of exposure to soil contaminants, the hazard quotient (HQ), which is the ratio of the exposure dose to the RfD, is calculated for each contaminant. The noncarcinogenic HQ assumes that below a given level of exposure (e.g., the RfD), even sensitive populations are unlikely to experience adverse health effects. If the exposure level exceeds the threshold there may be concern for potential noncarcinogenic health effects.

HQs are summed for each exposure pathway to create a pathway specific hazard index (HI) for each exposure scenario. The more the HI exceeds unity (1.0), the greater the concern that adverse health effects will occur.

The reasonable maximum exposure concentration value was used as the exposure point concentration. 


\section{Current Land Use - Noncarcinogenic Hazards}

Table 1 provides a summary of the noncarcinogenic hazard indices and applicable constituents of concern (COCs) associated with the current land use scenario for the BRRP unit soils.

The total noncarcinogenic (noncancer) hazard index did not exceed unity for the environmental researcher receptor evaluated in the current land use scenario. This indicates that potential adverse health effects are not likely to occur for the current environmental researcher.

\section{Current Land Use - Carcinogenic Risks}

Table 2 provides a summary of the carcinogenic risks and applicable COCs associated with the current land use scenario for the BRRP unit soils.

Under the current land use scenario, the total carcinogenic (cancer) risk (for chemicals and radionuclides) did not exceed a level of $1.0 \times 10^{-6}$ for the environmental researcher which indicates that carcinogenic risk from the unit soils is not significant.

\section{Future Land Use - Noncarcinogenic Hazards}

Table 3 provides a summary of the noncarcinogenic hazard indices and applicable COCs associated with the future land use scenario for the BRRP unit soils.

The HIs were all less than one, indicating that adverse noncarcinogenic effects are unlikey for the following pathways:

- incidental ingestion of soil,

- dermal contact with soil (based on exposure to the face, arms,

- inhalation of chemicals in ambient air, and

- ingestion of homegrown produce.

\section{Future Land Use - Carcinogenic Risks}

For the future residential adult, the only estimated risk from the unit soils was the ingestion of arsenic with a risk value of 1.9 $x 10^{-6}$. And, for the future residential child, the only estimated risk from the unit soils was the ingestion of arsenic with a risk value of $2.8 \times 10^{-6}$. The arsenic level associated with both risks was $1.74 \mathrm{mg} / \mathrm{kg}$. It should be noted that arsenic was used as a component of agricultural chemicals in the period before SRS existed. Thus, the detected value may be a result of farming activities in the 1930's through 1950.

Table 4 provides a summary of the carcinogenic risks and applicable COCs associated with the future land use scenario for the BRRP unit soils.

\section{Ecological Risk Assessment}

A screening-level ecological risk assessment was conducted to assess the potential impacts to biota caused by exposure to chemicals and radionuclides at the BRRP.

A site ecological reconnaissance was conducted in August 1994. No wetlands or threatened and endangered (T\&E) species were observed in the vicinity of the BRRP, and use of the site by $T \& E$ species was not expected. The potential media of contaminant exposure were surface soil, sediment, and surface water at or near the BRRP.

Based on the screening-level ecological risk assessment, ecological impacts from the BRRP source unit are unlikely.

\section{Section IV.C Summary of the Considered Alternative}

Based on the baseline risk assessment, the BRRP source unit soils pose minimal risk to human health or the environment. Therefore, no action is required at the BRRP source unit soils and no other altenatives were considered for the source unit soils. Only non-hazardous; inert material (e.g., 
Table 1 - Current Land Use - Noncarcinogenic Hazard Index

\begin{tabular}{|l|l|l|l|l|l|}
\hline RECEPTOR & \multicolumn{4}{|c|}{ EXPOSURE TO CHEMICALS (HAZARD INDEX) } \\
\hline & $\begin{array}{l}\text { Soil - } \\
\text { Ingestion }\end{array}$ & $\begin{array}{l}\text { Soil - } \\
\text { Dermal }\end{array}$ & $\begin{array}{l}\text { Soil - } \\
\text { Inhalation }\end{array}$ & $\begin{array}{l}\text { Total (Soils } \\
\text { Only) }\end{array}$ & COCs \\
\hline $\begin{array}{l}\text { Environmental } \\
\text { Researcher - ST \& LT }\end{array}$ & 0.041 & 0.024 & 0.0000034 & 0.065 & NA \\
\hline
\end{tabular}

Table 2 - Current Land Use - Carcinogenic Risks

\begin{tabular}{|l|l|l|l|l|l||}
\hline RECEPTOR & \multicolumn{5}{|c|}{ EXPOSURE TO CHEMICALS } \\
\hline & $\begin{array}{l}\text { Soil - } \\
\text { Ingestion }\end{array}$ & $\begin{array}{l}\text { Soil - } \\
\text { Dermal }\end{array}$ & $\begin{array}{l}\text { Soil - } \\
\text { Inhalation }\end{array}$ & $\begin{array}{l}\text { Total (Soils } \\
\text { Only) }\end{array}$ & COCs \\
\hline $\begin{array}{l}\text { Environmental } \\
\text { Researcher - ST }\end{array}$ & $3.2 \times 10^{-9}$ & $3.4 \times 10^{-10}$ & $2.6 \times 10^{-11}$ & $3.6 \times 10^{-9}$ & NA \\
\hline $\begin{array}{l}\text { Environmental } \\
\text { Researcher - LT }\end{array}$ & $1.6 \times 10^{-7}$ & $1.7 \times 10^{-8}$ & $1.3 \times 10^{-9}$ & $1.8 \times 10^{-7}$ & NA \\
\hline RECEPTOR & \multicolumn{5}{|c|}{ EXPOSURE TO RADIONUCLDES } \\
\hline & $\begin{array}{l}\text { Soil - } \\
\text { Ingestion }\end{array}$ & $\begin{array}{l}\text { Soil - } \\
\text { External }\end{array}$ & $\begin{array}{l}\text { Soil - } \\
\text { Inhalation }\end{array}$ & $\begin{array}{l}\text { Total (Soils } \\
\text { Only) }\end{array}$ & COCs \\
\hline $\begin{array}{l}\text { Environmental } \\
\text { Researcher -ST }\end{array}$ & $5.3 \times 10^{-12}$ & $1.9 \times 10^{-8}$ & $1.6 \times 10^{-15}$ & $1.9 \times 10^{-8}$ & NA \\
\hline $\begin{array}{l}\text { Environmental } \\
\text { Researcher - LT }\end{array}$ & $1.5 \times 10^{-10}$ & $7.1 \times 10^{-8}$ & $1.2 \times 10^{-14}$ & $7.1 \times 10^{-8}$ & NA \\
\hline
\end{tabular}

Table 3 - Future Land Use - Noncarcinogenic Hazard Index

\begin{tabular}{|l|l|l|l|l|l|l||}
\hline \hline RECEPTOR & \multicolumn{5}{|c|}{ EXPOSURE TO CHEMICALS (HAZARD INDEX) } \\
\hline & $\begin{array}{l}\text { Soil - } \\
\text { Ingestion }\end{array}$ & $\begin{array}{l}\text { Soil - } \\
\text { Dermal }\end{array}$ & $\begin{array}{l}\text { Soil - } \\
\text { Inhalation }\end{array}$ & $\begin{array}{l}\text { Produce - } \\
\text { Ingestion }\end{array}$ & $\begin{array}{l}\text { Total (Soils } \\
\text { Only) }\end{array}$ & COCs \\
\hline $\begin{array}{l}\text { Environmental } \\
\text { Researcher - ST \& } \\
\text { LT }\end{array}$ & 0.041 & 0.024 & 0.0000034 & NA & 0.065 & NA \\
\hline $\begin{array}{l}\text { Residential } \\
\text { Adult - ST \& LT }\end{array}$ & 0.026 & 0.029 & 0.0000027 & 0.00013 & 0.055 & NA \\
\hline $\begin{array}{l}\text { Residential } \\
\text { Child -ST }\end{array}$ & 0.23 & 0.11 & 0.000013 & 0.00030 & 0.34 & NA \\
\hline $\begin{array}{l}\text { Occupational } \\
\text { Worker - ST \& LT }\end{array}$ & 0.14 & 0.083 & 0.000024 & NA & 0.22 & NA \\
\hline
\end{tabular}

COCs - Constituents of Concern LT - Long Term
ST - Short Term

NA - Not Applicable 
Table 4 - Future Land Use - Carcinogenic Risks

\begin{tabular}{|c|c|c|c|c|c|c|}
\hline RECEPTOR & \multicolumn{6}{|c|}{ EXPOSURE TO CHEMICALS } \\
\hline 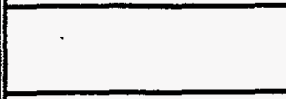 & \begin{tabular}{|l|} 
Soil - \\
Ingestion \\
\end{tabular} & \begin{tabular}{|l|} 
Soil - \\
Dermal \\
\end{tabular} & \begin{tabular}{|l|} 
Soil - \\
Inhalation \\
\end{tabular} & \begin{tabular}{|l|} 
Produce - \\
Ingestion \\
\end{tabular} & \begin{tabular}{|l|} 
Total (Soils \\
Only) \\
\end{tabular} & COCs \\
\hline $\begin{array}{l}\text { Environmental } \\
\text { Researcher - ST }\end{array}$ & $3.2 \times 10^{-9}$ & $3.4 \times 10^{-10}$ & $2.6 \times 10^{-11}$ & NA & $3.6 \times 10^{-9}$ & NA \\
\hline $\begin{array}{l}\text { Environmental } \\
\text { Researcher - LT }\end{array}$ & $1.6 \times 10^{-7}$ & $1.7 \times 10^{-8}$ & $1.3 \times 10^{-9}$ & NA & $1.8 \times 10^{-7}$ & NA \\
\hline $\begin{array}{l}\text { Residential } \\
\text { Adult - ST }\end{array}$ & $3.1 \times \cdot 10^{-7}$ & $1.6 \times 10^{-8}$ & $7.5 \times 10^{-9}$ & $2.0 \times 10^{-8}$ & $3.5 \times 10^{-7}$ & NA. \\
\hline $\begin{array}{l}\text { Residential } \\
\text { Adult - LT }\end{array}$ & $1.9+10^{-6}$ & $9.8 \times 10^{-8}$ & $4.5 \times 10^{-8}$ & $1.2 \times 10^{-7}$ & $2,2,2,100^{6}$ & Arsenic \\
\hline $\begin{array}{l}\text { Residential } \\
\text { Child - ST }\end{array}$ & $28 \times 10^{-6}$ & $6.4 \times 10^{-8}$ & $3.6 \times 10^{-8}$ & $4.4 \times 10^{-8}$ & $29 \times 10^{6}$ & Arsenic \\
\hline $\begin{array}{l}\text { Occupational } \\
\text { Worker - ST }\end{array}$ & $1.1 \times 10^{-7}$ & $1.2 \times 10^{-8}$ & $1.8 \times 10^{-9}$ & NA & $1.2 \times 10^{-7}$ & NA \\
\hline $\begin{array}{l}\text { Occupational } \\
\text { Worker - LT }\end{array}$ & $5.6 \times 10^{-7}$ & $5.8 \times 10^{-8}$ & $9.0 \times 10^{-9}$ & $\mathrm{NA}$ & $6.3 \times 10^{-7}$ & $\overline{N A}$ \\
\hline \multirow[t]{2}{*}{ RECEPTOR } & \multicolumn{6}{|c|}{ EXPOSURE TO RADIONUICLIDES } \\
\hline & \begin{tabular}{|l|} 
Soil - \\
Ingestion \\
\end{tabular} & \begin{tabular}{|l|} 
Soil - \\
External \\
\end{tabular} & \begin{tabular}{|l|} 
Soil - \\
Inhalation \\
\end{tabular} & \begin{tabular}{|l} 
Produce - \\
Ingestion
\end{tabular} & \begin{tabular}{|l|} 
Total (Soils \\
Only) \\
\end{tabular} & $\mathrm{COCs}$ \\
\hline $\begin{array}{l}\text { Environmental } \\
\text { Researcher - ST }\end{array}$ & $5.3 \times 10^{-12}$ & $1.9 \times 10^{-8}$ & $1.6 \times 10^{-15}$ & NA & $1.9 \times 10^{-8}$ & NA \\
\hline $\begin{array}{l}\text { Environmental } \\
\text { Researcher - LT } \\
\end{array}$ & $1.5 \times 10^{-10}$ & $7.1 \times 10^{-8}$ & $1.2 \times 10^{-14}$ & $\overline{N A}$ & $7.1 \times 10^{-8}$ & $\mathrm{NA}$ \\
\hline $\begin{array}{l}\text { Residential } \\
\text { Adult - ST }\end{array}$ & $4.0 \times 10^{-10}$ & $2.6 \times 10^{-7}$ & $2.1 \times 10^{-13}$ & $2.8 \times 10^{-14}$ & $2.6 \times 10^{-7}$ & NA \\
\hline $\begin{array}{l}\text { Residential } \\
\text { Adult - LT }\end{array}$ & $1.6 \times 10^{-9}$ & $3.6 \times 10^{-7}$ & $3.7 \times 10^{-13}$ & $1: 1 \times 10^{-13}$ & $3.6 \times 10^{-7}$ & $\overline{N A}$ \\
\hline $\begin{array}{l}\text { Residential } \\
\text { Child - ST }\end{array}$ & $8.3 \times 10^{-10}$ & $2.6 \times 10^{-7}$ & $2.4 \times 10^{-13}$ & $1.5 \times 10^{-14}$ & $2.6 \times 10^{-7}$ & NA \\
\hline $\begin{array}{l}\text { Occupational } \\
\text { Worker - ST }\end{array}$ & $1.4 \times 10^{-10}$ & $7.8 \times 10^{-8}$ & $5.0 \times 10^{-14}$ & NA & $7.8 \times 10^{-8}$ & $\mathrm{NA}$ \\
\hline $\begin{array}{l}\text { Occupational } \\
\text { Worker - LT }\end{array}$ & $9.0 \times 10^{-10}$ & $1.1 \times 10^{-7}$ & $8.5 \times 10^{-14}$ & $\mathrm{NA}$ & $1.1 \times 10^{-7}$ & NA \\
\hline
\end{tabular}

Shadeded items represent exceedances.

ST - Short Term
LT - Long Term
COCs - Constituents of Concern

NA - Not Applicable 
wood, trash, wire, bottles, plastic, rubble, foam, concrete, etc.) was placed at the BRRP source unit. A notification will be placed in the Aiken County Records which will include a survey plat of the area prepared and certified by a professional land surveyor.

Although there is groundwater contamination (e.g., carbon tetrachloride, bis (2-ethylhexyl) phthalate, nitrate, cesium-137, radium, and tritium, ) beneath the BRRP, the groundwater contamination is due to migration from upgradient sources such as the F-Area Inactive Process Sewer Lines and thus will not be addressed in this remedial action. Following an investigation on upgradient groundwater contaminant sources, a determination will be made as to what corrective action might be appropriate for the groundwater beneath the BRRP.

This proposal is consistent with EPA guidance and an effective use of risk management principles.

\section{Description of the Preferred Alternative}

The No Action Alternative includes the following components:

Treatment Components - No treatment would be implemented.

Engineering Controls - No engineering controls would be required.

Institutional Controls - The BRRP is included in the industrial zone for the SRS. Access to the SRS is controlled at primary roads by continuously manned barricades. Other roads entering the site are closed to traffic by gates or barriers. The entire SRS facility is surrounded by an exclusion fence, except along the Savannah River. The SRS is posted against trespassing under state and federal statutes.

Quantity of Waste - There are no wastes associated with the BRRP.
Implementation Requirements - This alternative is readily implementable.

Estimated Construction and Operation and Maintenance Costs - There are no costs associated with the No Action alternative.

Applicable or Relevant and Appropriate Requirements (ARARs) Associated with the Considered Alternative - There are no ARARs associated with the No Action alternative.

\section{Section IV.D Summary of the No Action Alternative}

According to EPA guidance document OSWER Directive 9355.3-02 if there is no current or potential threat to human health and the environment and no action is warranted, the CERCLA 121 requirements are not triggered. This means that there is no need to evaluate against the nine criteria specified under CERCLA.

Since the BRRP source unit soils pose minimal known risk to human health and the environment, its further evaluation under CERCLA is unwarranted. The no action alternative is intended to be the final action for the BRRP source unit soils only. This solution is meant to be permanent and effective in both the long and short term. The no action decision is the least cost option with no capital, operating, or monitoring costs, and is protective of human health and the environment. Additionally, this plan provides for involvement with the community through a document review process and a public comment period. Public input will be documented in the ROD. 


\section{REFERENCES}

DOE (U.S. Department of Energy), 1994. Public Involvement, A Plan for the Savannah River Site. Savannah River Operations Office, Aiken, South Carolina.

EPA (U.S. Environmental Protection Agency), 1991a. Role of the Baseline Risk Assessment in Superfund Remedy Selection Decisions. Office of Solid Waste and Emergency Response OSWER Directive 9355.0-30.

EPA (U.S. Environmental Protection Agency), 1989. Guidance on Preparing Superfund Decision Documents. Office of Solid Waste and Emergency Response OSWER Directive 9355.3-02.

FFA, 1993. Federal Facility Agreement for the Savannah River Site, Administrative Docket No. 89-05-FF, (Effective Date: August 16, 1993).

WSRC (Westinghouse Savannah River Company). Final RFI/RI Report for Burma Road Rubble Pit (231-4F) (U), W S R C - R P - 94-1217, Rev. 1, Westinghouse Savannah River Company, Aiken, South Carolina (1995; includes the Baseline Risk Assessment).

WSRC (Westinghouse Savannah River Company). Phase II RFI/RI Work Plan for the Burma Road Rubble Pit (231-4F) (U), W S R C-R P-90-1104, Rev. 2, Westinghouse Savannah River Company, Aiken, South Carolina (1993).

WSRC (Westinghouse Savannah River Company). Quality Control Summary Report for the Burma Road Rubble Pit RFI/RI Unit Assessment (U), ESH-EMS94-0425, Westinghouse Savannah River Company, Aiken, South Carolina (1994). 


\section{GLOSSARY}

Administrative Record File: A file that is maintained and contains all information used to make a decision on the selection of a response action under the Comprehensive Environmental Response, Compensation, and Liability Act. This file is to be available for public review, and a copy is to be established at or near the Site, usually at one of the information repositories. Also, a duplicate file is held in a central location, such as a regional or state office.

ARARs: Applicable or Relevant and Appropriate Requirements. Refers to the federal and state requirements that a selected remedy will attain. These requirements may vary from site to site.

Baseline Risk Assessment: An analysis of the potential adverse health effects (current or future) caused by hazardous substance release from a site in the absence of any actions to control or mitigate these releases.

Characterization: The compilation of all available data about the waste units to determine the rate and extent of contaminant migration resulting from the waste site, and the concentration of any contaminants that may be present.

Comprehensive Environmental Response, Compensation, and Liability Act (CERCLA): Comprehensive Environmental Response, Compensation, and Liability Act of 1980 which is commonly referred to as CERCLA was amended by the Superfund Amendments Reauthorization Act (SARA) of 1986.

Contamination: The deposition of unwanted chemical and/or radioactive material at a site.

Corrective Action: An order EPA issues requiring remedial procedures under RCRA 3008(h) at a facility when there has been a release of hazardous waste or constituents into the environment. Corrective action may be required beyond the facility boundary and can be required regardless of when the waste was placed at the facility.

Exposure: Contact of an organism with a chemical or physical agent. Exposure is quantified as the amount of the agent available at the exchange boundaries of the organism (e.g., skin, lungs, digestive tract) and available for absorption.

Federal Facility Agreement (FFA): The legally binding agreement between regulatory agencies (EPA and SCDHEC) and regulated entities (DOE) that sets the standards and schedules for the comprehensive remediation of the SRS.

Magnetometer: A device used to locate buried metallic objects which create a measurable disturbance in the magnetic field of the earth.

Media: A pathway through which contaminants are transferred. Five media by which contaminants may be transferred are groundwater, soil, surface water, sediments, and air.

National Priorities List (NPL): Formal listing of the nation's worst contaminated sites, as established by the Comprehensive Environmental Response, Compensation, and Liability Act.

Operable Unit: Defined in the regulations as a discrete action taken as one part of an overall site cleanup. The term is also used in EPA guidance documents to refer to distinct geographic areas or media-specific units within a site. A number of operable units can be used in the course of a cleanup.

Operation and Maintenance (O\&M): Activities conducted at a site after a response action occurs to ensure that the cleanup and/or systems are functioning properly.

Overall Protection of Human Health and. the Environment: The assessment against this criterion describes how the 
alternative, as a whole, achieves and maintains protection of human health and the environment.

Proposed Plan: A legal document that provides a brief analysis of remedial alternatives under consideration for the site/operable unit and proposes the preferred alternative.

Reduction of Toxicity, Mobility, and Volume through Treatment: The assessment against this criterion evaluates the anticipated performance of the specific treatment technologies an alternative may employ.

Resource Conservation and Recovery Act (RCRA): Resource Conservation and Recovery Act of 1976 which is commonly referred to as RCRA, is an amendment to the first federal solid waste legislation, called the Solid Waste Disposal Act of 1965. RCRA was amended in 1980 and most recently on November 8, 1984 by the Hazardous and Solid Waste Act.

Record of Decision (ROD): A legal document that describes the final remedial actions selected for a site, why the remedial actions were chosen, and how the public responded to the proposed remedial actions.

Responsiveness Summary: A summary of oral and/or written comments received during the proposed plan comment period.

Superfund: The common name used for the Comprehensive Environmental Response, Compensation, and Liability Act. The superfund program was established to help fund cleanup of hazardous waste sites. It also allows for legal action to force those responsible for the sites to clean them up. 
DOCUMENT APPROVAL SUMMARY

PROPOSED PLAN FOR THE BURMA ROAD RUBBLE PIT (231-4F)

(Rev. 1, November 1995)

\section{DOE FIELD OFFICE}

Savannah River Operations Office.

\section{DOCUMENT}

Proposed Plan for the Burma Road Rubble Pit (231-4F) (U) - November 1995 (Rev. 1).

\section{REGULATORY SUMMARY}

The Burma Road Rubble Pit (BRRP) is subject to both Resource Conservation and Recovery Act (RCRA) 3004(u) and Comprehensive Environmental Response, Compensation, and Liability Act (CERCLA) requirements. The Proposed Plan for the Burma Road Rubble Pit (231-4F) source unit was prepared to satisfy CERCLA requirements to provide a description of the preferred alternative selected for the BRRP source unit.

No action has been selected as the preferred alternative for the BRRP source unit. No action was selected since the results of the RCRA Facility Investigation (RFI)/Remedial Investigation (RI) indicates that the soil from the BRRP source unit pose no threat to human health or the environment. Only non-hazardous, inert material (i.e., wood, trash, wire, bottles, plastic, concrete, etc.) was placed at the BRRP source unit. A notification will be placed in the Aiken County Records which will include a survey plat of the area prepared and certified by a professional land surveyor.

Although there is groundwater contamination (e.g., carbon tetrachloride, bis(2ethylhexyl)phthalate, nitrate, cesium-137, radium, and tritium) beneath the BRRP source unit, there is no evidence that this source unit attributed to the contamination. The groundwater contamination is potentially due to migration from upgradient sources such as the F-Area Inactive Process Sewer Lines. Following an investigation on upgradient groundwater contaminant sources, a determination will be made as to what corrective action might be appropriate.

\section{BACKGROUND}

The Burma Road Rubble Pit, 231-4F, is approximately one-half mile southwest of the F-Area Separations Facility and one-tenth mile southwest of C Road. The BRRP is located between Upper Three Runs Creek (approximately 4000 feet to the northwest) and Four Mile Creek (approximately one mile to the southwest).

The BRRP was used from 1973 to 1983 for the disposal of dry inert rubble such aswood, trash, wire, bottles, plastic, concrete, etc. No record of disposal of hazardous substances at the BRRP has been found. In 1983, the BRRP was closed by covering it with soil. The area is currently designated by orange marker balls at the perimeter of the source unit.

The BRRP consists of two unlined earthen pits dug into surficial soil and filled with various waste materials. The BRRP was originally reported to be 485 feet long, 125 to 150 feet wide, and at least 10 feet deep. A ground penetrating radar survey indicated that the BRRP area consists of 
two generally rectangular pits, each about 400 feet long, up to 50 feet wide, and 10 feet deep. A small circular area of disturbed soil was detected adjacent to these pits and may have been used as a souice of backfill for the pits.

The RFI/RI for the BRRP was conducted from November 1993 to February 1994 in order to determine whether hazardous substances were present in the subsurface soils, to evaluate the nature and extent of contamination, and to evaluate the risks posed to the SRS facility due to activities conducted at the BRRP. During the investigation, none of the soil borings encountered any containers (i.e., drums), liquid, sludge, or experienced a rod-drop that would indicate a drum or container had been punctured. Only non-hazardous, inert material (i.e., wood, trash, wire, bottles, plastic, rubble, foam, concrete, etc.) were encountered during the soil sampling.

Under the current use scenario, the total noncancer hazard indices did not exceed unity for the environmental researcher. Similarly, the total carcinogenic risk did not exceed a level of $1 \times 10^{-6}$ for the environmental researcher.

The total noncancer hazard indices for the hypothetical future environmental researcher were below unity. The total noncancer hazard index for the future receptor exceeded unity for the hypothetical future resident (adult and child) scenarios. Nitrate was the primary contributor for the exceedance. The future residential child scenario also resulted in other cases where the total noncancer hazard index exceeded unity. The primary contributors were arsenic and carbon tetrachloride.

The estimated risks from the unit soils for the future residential adult and future residential child were $1.9 \times 10^{-6}$ and $2.8 \times 10^{-6}$, respectively. Arsenic was the risk driver in both cases. The arsenic level associated with the risks was $1.74 \mathrm{mg} / \mathrm{kg}$. SRS background concentrations for arsenic averaged $2.2 \mathrm{mg} / \mathrm{kg}$. Since arsenic was used as a component of agricultural chemicals in the period before SRS existed, the detected arsenic value may be a result of farming activities in the 1930's through 1950.

For the hypothetical future residential adult, the chemicals associated with carcinogenic risks above $1.0 \times 10^{-6}$ included arsenic, beryllium, carbon tetrachloride, and bis(2-ethylhexyl) phthalate. Cesium-137, radium, and tritium were the radionuclides associated with carcinogenic risks above $1.0 \times 10^{-6}$. For the hypothetical future child, arsenic, beryllium, carbon tetrachloride, radium, and tritium were the risk drivers for carcinogenic risks above $1.0 \times 10^{-6}$. The future occupational worker had arsenic, beryllium, carbon tetrachloride, cesium-137, radium, and tritium as the risk drivers for carcinogenic risks above $1.0 \times 10^{-6}$.

Comparison of the groundwater contaminants beneath the BRRP to upgradient wells (e.g., the FArea Inactive Process Sewer Line (FSL) wells), showed that the carbon tetrachloride, bis(2ethylhexyl)phthalate, nitrate, cesium-137, radium, and tritium contamination found in the BRRP groundwater wells were the result of upgradient migration. There was insufficient data available to ensure that the arsenic and beryllium concentrations found in the BRRP groundwater were the result of upgradient migration. It should be noted that the groundwater contamination will be addressed following an investigation on upgradient groundwater contamination.

Based on the screening-level ecological risk assessment, ecological impacts from the BRRP are unlikely.

\section{DOCUMENT APPROVAL}

The Proposed Plan for the Burma Road Rubble Pit (231-4F) concludes that no action is required at the source unit soils. It also concludes that since groundwater contamination beneath the 
BRRP is potentially from an upgradient source, the groundwater contamination in the area will be addressed following an investigation on upgradient groundwater contaminant sources.

DOE, WSRC, EPA and SCDHEC comments have been incorporated and are reflected in this document.

Document approval is requested by November 21,1995 in order to meet a regulatory submittal date of November 24, 1995.

\section{ATTACHMENTS}

Proposed Plan for the Burma Road Rubble Pit (231-4F) (Rev. 1, November 1995)

EPA Comments and Responses

SCDHEC Comments and Responses 
Below are comments provided by the Environmental Protection Agency (EPA) on the Proposed Plan for the Burma Road Rubble Pit (231-4F), WSRC-RP-95-1531, dated August 1995. Responses are in bold type.

\section{GENERAL COMMENTS}

1. This proposed plan addresses the Burma Road Rubble Pit (231-4F) source unit and its impact on underlying groundwaters. The investigation of this site has revealed no impact to groundwater from this source unit. Additionally, the materials found in this source unit suggest that they are not hazardous waste. Hence, the justification for the no further investigation/action decision. Currently, this proposed plan does not clearly identify this decision as being limited to only the Burma Road Rubble Pit SOURCE unit. Too much emphasis is placed on the groundwater in the decision making process for this source unit.

The statement should be made that the groundwater is potentially contaminated from upgradient sources and not as a result of this source unit. It should be added that further investigation will be performed to determine the potential contamination from upgradient areas and that any remedial actions on the groundwater beneath the Burma Road Rubble Pit $(231-4 \mathrm{~F})$ will only be associated with those upgradient areas of contamination. The risk calculations and further discussions regarding groundwater for this source unit should be either totally removed or greatly reduced from the way they exist presently.

RESPONSE: Agree. The proposed plan was revised accordingly.

2. EPA recognizes that this proposed plan also serves as a mini-baseline risk assessment. However, this should be clarified within this document.

RESPONSE: Agree. The proposed plan was revised accordingly.

3. The use of the words "EPA - IV" should be changed to just EPA.

RESPONSE: Agree. The proposed plan was revised accordingly.

4. All references to the Burma Road Rubble Pit should clearly identify this unit as a source operable unit.

RESPONSE: Agree. The proposed plan was revised accordingly.

\section{SPECIFIC COMMENTS}

1. Executive Summary, page 1, first paragraph, last sentence: The first reference to CERCLA should read: "Section 117 (a) of the Comprehensive Environmental Response, Compensation, and Liability Act (CERCLA), as amended, requires...". This is the only time the phrase "as amended" need appear.

\section{RESPONSE: Agree. The Executive Summary was revised accordingly.}

2. Executive Summary, page 1, first paragraph, last sentence: The term "(e.g., the PP)" should be changed (if not deleted) to "(i.e., the PP)." 
RESPONSE: Agree. The term was deleted from the Executive Summary.

3. Executive Summary, page 1, fourth paragraph: The text states "one in one million EPA: target" without providing an explanation of what that means. Please clarify what this EPA Target value means to the public audience.

RESPONSE: Agree. The Executive Summary was revised accordingly.

4. Executive Summary, page 1, fourth paragraph: For clarity the value $1.0 \times 10^{-06}$ could either be deleted (because to already state "one in one million" previous to this value) or the value should be presented as $1.0 \times 10^{-6}$.

RESPONSE: Agree. The value was deleted from the Executive Summary.

5. Executive Summary, page 1, fifth paragraph: Change the text from "If required, it is proposed that any groundwater contamination..." to "Following an investigation on upgradient groundwater contaminant sources, a determination will be made as to what corrective action might be appropriate.

\section{RESPONSE: Agree. The Executive Summary was revised accordingly.}

6. Executive Summary, page 1, Sixth paragraph: Change "Based on the results of the remedial..." to "Based on the results of the remedial investigation, it is proposed that no remedial action is necessary for this source unit.

RESPONSE: Agree. The Executive Summary was revised accordingly.

7. Executive Summary, page 2, First paragraph: Because no hazardous waste exists at this site, EPA does not believe it necessary to post signs stating that inert material has been buried at this location. The paragraph's next sentence meets the need in notifying any potential buyer of the condition of the property.

\section{RESPONSE: Agree. The Executive Summary was revised accordingly.}

8. Executive Summary, page 2, Second paragraph: Add the word "source" following the use of the abbreviation BRRP, to read "BRRP source unit." This will focus the reader on what this proposed plan addresses. Do this throughout the document where appropriate.

RESPONSE: Agree. The proposed plan, including the Executive Summary, was revised accordingly.

9. Section I, Introduction, page 3, Fifth paragraph, Fourth sentence: The statement that "DOE, in consultation with EPA and SCDHEC, will select the final remedial action...." is not correct. The sentence should read "Following input from the public, EPA and SCDHEC will choose the appropriate final remedial technology to be performed at the BRRP source unit."

RESPONSE: Disagree. DOE, as well as EPA and SCDHEC, is a part of the tri-party agreement; and, therefore, should be included in the selection of the final remedial action for the BRRP source unit. The language in this proposed plan has been used in 
previous proposed plans. Examples of these proposed plans include the Interim Action Proposed Plan for the TNX Groundwater Operable Unit, the Interim Action Proposed Plan for the Par Pond Unit, and the final Proposed Plan for M-Area West.

10. Section II, Community Involvement, page 7, Right column, Third paragraph: The sentence "DOE will provide opportunity for a public meeting during..." should be changed to read "DOE will provide opportunity for a public meeting during the public comment period if interest is expressed." The use of the "significant" makes this read as if you do not wish to discuss this proposal with the public. DOE/SRS can define what level of interest is appropriate to hold a public meeting, but you do not want to convey to the public that a meeting would only be held if "significant" numbers of people wish to hold one.

\section{RESPONSE: Agree. Section II was revised accordingly.}

11. Section II, Community Involvement, page 7, Right column, Last paragraph, Last sentence: Please change the sentence "A Responsiveness Summary to address significant issues will be made available following the public comment period." to "A Responsiveness Summary to address issues raised by the public will be made available following the public comment period, if any comments have been received."

\section{RESPONSE: Agree. Section II was revised accordingly.}

12. Section III, page 9, Second paragraph: Again a reference to a sign posted around the BRRP. Unless this satisfies some sort of DOE Order or WSRC policy, EPA believes that it is unnecessary. The deed notice is all that would be appropriate for any future land owner, because this is not a hazardous waste site.

\section{RESPONSE: Agree. Section III was revised accordingly.}

13. Section III, page 9, Right column, Third paragraph: Change the reference to future groundwater action per comment Number five (5).

\section{RESPONSE: Agree. Section III was revised accordingly.}

14. Section III, page 9, Right column, Last paragraph: This paragraph is appropriate in conveying the action for this source unit and its lack of contribution to contamination of the underlying groundwater. Little to nothing more should be stated regarding the groundwater for this source operable unit.

\section{RESPONSE: Agree. Section III was revised accordingly.}

15. Section IV.A, page 14, Left column, Last paragraph: Information regarding aquifers beneath the Burma Road Rubble Pit, while interesting, is not relevant for this source unit.

- RESPONSE: Agree. Clarification. Specific information on groundwater data has been deleted from the text of the BRRP Proposed Plan since the remedial action in the proposed plan is for the BRRP soils only. The groundwater is only mentioned as requested in comment \#5.

16. Section IV.B, page 16, Left column, Second paragrajph: The discussion regarding risk from drinking the groundwater should be summarized, in that it will be addressed if necessary 
SRS Responses to EPA Comments on the DOE Savannah River Site

Proposed Plan for the Burma Road Rubble Pit (231-4F)

(WSRC-RP-95-1531) (Rev. 0), dated August 1995

due to other upgradient operable unit releases. This information serves to confuse the reader about how this source unit can be "clean" with contamination existing beneath it.

RESPONSE: Agree. Section IV.B was revised accordingly.

17. Section IV.B, page 17, Left column, Second paragraph: Same as comment Number sixteen (16) above.

RESPONSE: Agree. Section IV.B was revised accordingly.

18. Section IV.D, page 20, Summary of the No Action Alternative, Second paragraph, First sentence: Change the sentence to read: "Since the BRRP source unit poses no known risk to human health and the environment, its further evaluation under CERCLA is unwarranted."

RESPONSE: Agree. Section IV.D was revised accordingly. 
Below are comments provided by the South Carolina Department of Health and Environmental Control (SCDHEC) on the Proposed Plan for the Burma Road Rubble Pit (231-4F), WSRC-RP95-1531, dated August 1995. Responses are in bold type.

1. Within the PP's Executive Summary (page 1), SRS states that the confirmed groundwater contamination surrounding the BRR is from an upgradient source(s) (i.e., the F-Area Inactive Process Sewer Lines) and that the groundwater cleanup will be addressed under the RCRA Corrective Action Plan to remediate contamination at the F- and H-Area Seepage Basins. SRS's RCRA Area Hazardous Waste Permit (issued September 5, 1995), Module III, Section C (F-Area Hazardous Waste Management Facility), and Section D (H-Area Hazardous Waste Management Facility) addresses corrective action procedures concerning the Inactive Process Sewer Lines. SRS should address the groundwater contamination surrounding the BRR utilizing the aforementioned hazardous waste permit conditions.

RESPONSE: Agree. The text has been revised to state: "Following an investigation on upgradient groundwater contaminant sources, a determination will be made as to what corrective action might be appropriate for the groundwater beneath the BRRP."

2. In the Executive Summary, the 2 nd and 4th paragraphs are inconsistent. Paragraph 2 states: "...waste unit poses no risk to human health or the environment." Paragraph 4 says: "The only soil contamination found at the BRRP unit was arsenic at a concentration of 1.74 $\mathrm{mg} / \mathrm{kg}$ which resulted in risks..." Paragraph 2 should be revised to say that there is some risk at the unit, however it is minimal. Additional pages that require this correction are: page 3, paragraph 2; page 9, paragraph 2; page 20, last paragraph.

RESPONSE: Agree. Paragraph 2 of the Executive Summary has been revised accordingly.

3. Paragraph 2 of the Executive Summary should be revised to clarify that the "no action" being proposed is for soils only. Please revise the paragraph.

RESPONSE: Agree. Paragraph 2 of the Executive Summary has been revised accordingly.

4. In paragraph 4, of the Executive Summary, a comparison of arsenic concentrations at the unit is made to the concentration of arsenic from the site-wide background levels at SRS. The department does not consider site-wide background data unit specific and therefore impertinent to the Burma Road Rubble Pit. This site-wide background comparison should be removed and replaced with unit specific background data.

RESPONSE: Agree. The proposed plan has been revised accordingly. The BRRP background concentration for arsenic averaged $3.34 \mathrm{mg} / \mathrm{kg}$ for subsurface soils (10-12 feet) and arsenic was not detected in the surface soils ( $0-2$ feet).

5. Paragraph 5, in the Executive Summary, should include a contingency that will allow the groundwater at the Burma Road Rubble unit to be addressed through subsequent documents if the groundwater contamination is not adequately addressed by the RCRA Corrective Action Plan.

RESPONSE: Agree. See the response to comment \#1. 
6. Page 14, third paragraph, please include the total number of wells at the Burma Road Rubble Unit for comparison purposes.

RESPONSE: Agree. The text has been revised accordingly. The total number of wells at the BRRP is 14 .

7. The title to Section IV.B mentions the term "operable unit". Neither previously in the Proposed Plan nor in this section, has the term been discussed. Please provide some discussion to clarify what is the operable unit for this unit.

RESPONSE: Agree. Section IV.B was revised accordingly. The following information was added to Section IV.B: "The BRRP operable unit investigation was the action that addressed the rubble pit (potential source term), surrounding soils, and the groundwater under the facility. This section summarizes the baseline risk assessment information associated with the BRRP operable unit. It should be noted, however, that the remedial action proposed by this plan is for the BRRP soils only. The groundwater contamination will be addressed following an investigation on congradient contaminant sources."

8. Please revise the "Current Land Use" paragraphs to include the actual values for the noncarcinogenic hazards and the carcinogenic risks.

RESPONSE: Agree. Clarification. The "Current Land Use" paragraphs have been revised to refer the reader to Table 1 for specific values for the noncarcinogenic hazards and to Table 2 for the carcinogenic risks. The "Current Land Use" paragraphs and tables only reference information concerning the BRRP source unit soils since the remedial action proposed is for the soils only.

9. Please include a table in the Proposed Plan that provides a breakdown of the carcinogenic and non-carcinogenic risks for each medium for each different land use scenario/receptor. This table should provide totals for each medium and an overall total for the whole unit.

RESPONSE: Agree. Clarification. Tables 1 through 4 have been added to the proposed plan. Table 1 shows the Current Land Use - Noncarcinogenic Hazards and Table 2 shows the Current Land Use - Carcinogenic Risks. Table 3 shows the Future Land Use - Noncarcinogenic Hazards and Table 4 shows the Future Land Use Carcinogenic Risks. The tables only reference information concerning the BRRP source unit soils since the remedial action proposed is for the soils only.

10. The "Future Land Use" scenarios need to be revised. At present, the text is difficult to understand and confusing to the reader.

RESPONSE: Agree. Clarification. The "Future Land Use" scenarios have been revised. The reader is referred to Table 3 for specific values for the noncarcinogenic hazards and to Table 4 for the carcinogenic risks. The "Future Land Use" paragraphs and tables only reference information concerning the BRRP source unit soils since the remedial action proposed is for the soils only. 
11. On page 16, please include the MCL's in the text for Carbon Tetrachloride and Nitrate for comparison purposes.

RESPONSE: Clarification. Based on other comments and subsequent revisions that were made to the Future Land Use - Noncarcinogenic Hazards, the MCL information is no longer included in the proposed plan since the remedial action recommended in the plan is for the BRRP source unit soils only.

12. The fourth paragraph on page 16 states: "The maximum concentration detected in the BRR wells was $2.32 \times 10^{-3} \mathrm{mg} / \mathrm{L}$ which is above the detection limit for arsenic, but is below the remediation goal for the F-Area Seepage Basins Remediation Project."

1. SRS should provide to the Department justification on why the inactive process sewer lines are not considered the source for arsenic.

2. Why have the sources changed? (i.e., F-Area Inactive Process Sewer Lines vs. FArea Seepage Basins)

3. What is the significance of the F-Area Seepage Basins Remediation Project to the Burma Road Rubble Pit?

RESPONSE: Clarification. Arsenic was considered a risk driver for the Aquifer C Screen Zone of the BRRP groundwater. Groundwater flow in this aquifer zone is similar to the upper aquifer zone of the Upper Three Runs Aquifer (water table aquifer). The F-Area Inactive Process Sewer Lines (FSL) wells are upgradient to the BRR wells, however, no FSL wells are screened in this aquifer zone. Since the F-Area Inactive Process Sewer Lines was the mechanism for transferring waste from the Separations Area to the F-Area Seepage Basins, SRS thought it was appropriate to compare groundwater concentrations in the FSB monitoring wells to the BRR well concentrations. The FSB wells will be representative of upgradient conditions in the Aquifer C Screen Zone. The information on the F-Area Seepage Basins Remediation Project was provided for information only. Specific information on groundwater data has been deleted from the text of the BRRP Proposed Plan since the remedial action in the proposed plan is for the BRRP soils only. The only mention of the BRRP groundwater is as noted in the response to comment \#1.

13. The executive summary does not sufficiently indicate the level of risk associated with the groundwater (e.g., no numbers are used, the general level of risk is not indicated). The risk levels should be more explicitly indicated for all media.

RESPONSE: Agree. The Executive Summary has been-revised accordingly.

14. In Section IV.C the carcinogenic risks are discussed relative to $1.0 \times 10^{-4}$. The appropriate risk level is $1 \times 10^{-6}$. The levels should be evaluated relative to RBC's or a risk level of $1 \mathrm{x}$ $10^{-6}$.

RESPONSE: Agree. Clarification. In Section IV.B, the carcinogenic risk levels were discussed relative to $1 \times 10^{-6}$. The information contained in Section IV.C regatding carcinogenic risk levels has been deleted. 
15. It appears that the fourth sentence of last paragraph of Section IV.D should read "The no action decision is the least...." as opposed to "The no action decisions the least...."

RESPONSE: Agree. The proposed plan has been revised accordingly.

16. On page 14, the last paragraph in the left column, the sentence "Aquifer $D$, the deepest aquifer," should read Aquifer B, the deepest aquifer. In the revised RFI/RI Proposed Plan the above sentence should be reworded.

RESPONSE: Agree. Clarification. The information on the groundwater aquifers has been deleted from the text of the BRRP Proposed PIan since the remedial action in the proposed plan is for the BRRP soils only. The only mention of the BRRP groundwater is as noted in the response to comment \#1. 